\title{
Staff Not Available
}

National Cancer Institute

\section{Source}

National Cancer Institute. Staff Not Available. NCI Thesaurus. Code C106486.

A staff member is or was not available. 